\title{
Gal Moji, Sebuah Fenomena Bahasa Jepang Ragam Surat Elektronik pada Komunitas Gal
}

\author{
NURZA ARIESTAFURI \\ Program Studi Bahasa Jepang U niversitas W idyatama \\ e-mail: nurza.ariestafuri@widyatama.ac.id
}

\begin{abstract}
ABST RAK
Dalam artikel ini, penulis memaparkan mengenai Gal moji yang merupakan salah satu fenomena bahasa Jepang dalam ragam surat elektonik di dunia maya. Huruf tersebut digunakan untuk menulis pesan singkat di telepon seluler oleh komunitas remaja putri yang disebut gal, dan menjadi sebuah fenomena sosiolinguistik yang cukup unik. Tujuan dari paparan ini adalah untuk mengetahui latar belakang, pembentukan, serta makna yang tersirat dalam penggunaan gal moji. M etode yang digunakan dalam pemaparan ini adalah deskriptif dengan pemusatan pada studi literatur, tidak hanya buku, melainkan juga blog serta media sosial yang memuat tulisan para native. Kesimpulan dari paparan singkat ini adalah penggunaan gal moji berkaitan erat dengan kerahasiaan dan perasaan pengirim pesan, kemudian pembentukan hurufnya pun bersifat manasuka yang merupakan kombinasi antara huruf Jepang (hiragana, katakana, kanji) dengan huruf Romawi, Rusia, Yunani, simbol matematika, dan bermacam-macam variasi karakter lainnya. Keyword: Gal, surat elektronik, pesan singkat, gal moji, sosisolinguistik
\end{abstract}

\section{ABSTRACT}

This article describes about Gal moji which is one of the phenomenon of Japanese language used in cyberspace communication, especially in electronic mail. Young girl community called Gal is using these letters to write short messages on cell phones, and this became a quite unique sociolinguistic phenomenon. The purpose of this research is to describe the background, letter's formation, and the meaning of Gal moji. The method used in this research is descriptive, focused on literature studies, from books, blogs and social media that contain writings of Japanese natives. Gal moji is closely related to the confidentiality of messages and feelings. The letters are in free-formed style which is a combination of Japanese letters (hiragana, katakana, kanji) with Roman, Russian, Greek, mathematical symbols, and variations of other characters.

Keyword: Gal, electronic mail, short message, gal moji, socisolinguistic

\section{PENDAHULUAN}

Bahasa digunakan sebagai alat untuk menyampaikan ide, pikiran, hasrat, dan keinginan kepada orang lain baik secara lisan maupun tulisan. Bahasa sebagai alat komunikasi antaranggota masyarakat akan terus berkembang seiring dengan perkemba- 
ngan zaman dan masyarakat penutur bahasa tersebut, dan tidak jarang hingga terjadi sebuah fen omena bahasa.

Fenomena bahasa banyak ditemukan dalam bahasa lisan. $\mathrm{N}$ amun, seiring den gan berkembangnya teknologi yang mendukung media berbahasa di dunia maya, maka tidak menutup kemungkinan fenomen abahasa muncul pula pada bahasa tulisan, seperti pada surat elektronik (email), blog, SMS (Short M essage Service), dan lain-lain.

Jepang sebagai negara dengan teknologi maju, dikenal sering membuat terobosan-terobosan baru dalam berbagai bidang, salah satunya adalah dalam bidang telekomunikasi. Telepon selular menjadi barang yang penting bagi masyarakat modern Jepang sejak NTT DoCoMo (perusahaan telekomunikasi Jepang) memulai bisnis I -M ode yang menyediakan akses internet untuk telepon selular di Jepang pada tahun 1999. D ari sinilah dimulainya kebiasaan mengirim surat elektronik melalui telepon selular.

Fenomen a saling berkirim surat el ektronik via telepon selular menjadi cikal bakal proses terjadinya fenomena pada bahasa tulisan, tepatnya pada ragam bahasa surat elektonik, dan biasanya fenomena ini diciptakan oleh kaum mudaJepang (Tanabe, 2005). $\mathrm{H}$ al tersebut didukung pula oleh fitur-fitur ponsel yang terus mengalami perkembangan dari waktu ke waktu. Beberapa fenomena yang terjadi di dalam bahasa Jepang ragam surat elektronik, di antaranya adalah penggunaan konten emoji, yaitu simbol bahasa yang berupa gambar, biasanya bentuk ekspresi wajah atau yang dikenal dengan sebutan emoticon (E motion I con), dan bisa pula berupa gambar benda-benda seperti tas, sepatu, bola, bunga dan lain -ain. Berikutnya, ada ka o moji, yaitu menyusun atau menggabungkan berbagai karakter (huruf, tanda baca, simbol) hingga membentuk ekspresi wajah tertentu.

Fenomena lainnya adalah $\mathrm{G}$ al moji ( $G$ yaru moji) yang menjadi topik bahasan pada artikel ini, yaitu huruf-huruf yang digunakan oleh komunitas yang disebut $\mathrm{G}$ al. $\mathrm{G}$ al sen diri mengacu pada gadisgadis muda yang terobsesi dengan konsumerisme di daerah Shibuya, salah satu distrik yang memberikan banyak kesenangan 
di daerah Tokyo. M ereka telah menciptakan gaya-gaya yang unik baik dalam berpakaian maupun dalam berkomunikasi antarsesama, salah satunya adalah gal moji yang disebutkan di atas.

\subsection{RU MU SAN MASALAH}

Berdasarkan uraian yang dikemukakan pada pendahuluan, rumusan masalah akan dijabarkan sebagai berikut:

1) A pakah yang melatarbelakangi terciptanya gal moji?

2) Bagaimanakah proses pembentukan serta penggunaan gal moji oleh para gal?

3) Apakah makna yang terkandung di balik pesan yang ditulis dalam gal moji?

4) Bagaimanakah reaksi masyarakat terhadap eksistensi gal moji?

\subsection{TUJUAN PENELITIAN}

Sesuai dengan penjabaran di atas, maka artikel ini bertujuan untuk menggali konstruksi dari dialek pada dunia maya, salah satu jenis dari sosio-dialek yang telah berkembang di ranah tersebut, dengan fokus sebagai berikut:

1) Memaparkan latar belakang terbentuknya gal moji.

2) M emaparkan proses dari pembentukan serta pen ggunaan gal moji dalam surat atau pesan elektronik.

3) Memaparkan kandungan nuansa dalam pesan yang ditulis dengan gal moji.

4) Mengetahui reaksi masyarakat terhadap eksistensi gal moji.

\section{PEMBAHASAN}

Pada bab sebelumnya telah sedikit dijelaskan mengenai komunitas gal sebagai pengguna gal moji. Sebelum mengarah kepada bahasan mengenai gal moji, penting untuk mengetahui lebih dalam mengenai seluk beluk gal terlebih dahulu karena karakteristik gal moji sangat erat kaitannya denga karakteristik gal itu sendiri.

\subsection{IHWAL GAL}

$\mathrm{G}$ al, atau orang Jepang biasa melafalkannya dengan "gyaru" adalah sebutan untuk gadis-gadis muda dengan penampilan mencolok. G al sendiri berasal dari kata slang bahasa Inggris "girl" 
yang berarti gadis muda. Istilah ini mulai mencuat setelah sebuah merek jin ternama, yaitu W rangler, mengeluarkan seri jin dengan nama "G als" padatahun 1972 yang khusus diperuntukkan untuk gadis remaja belasan tahun hingga yang menginjak usia 20 tahunan. Jin ini sangat populer dikalangan para gadis muda, sehingga pada era 70-an, istilah gals tidak hanya dikenal sebagai sebuah brand, melainkan berkembang menjadi sebuah sebutan untuk tren fashion terkini. Pada akhirnya, di penghujung era 80an hingga awal tahun 90-an, istilah gal resmi disematkan kepada para remaja atau gadis muda yang tampil dengan gaya fashion yang mencolok.

Pada era 90-an hingga 2000-an, gaya fashion gal berkembang terus menerus dan lebih terspesifikasi secara detail den gan seringnya majalah-majalah fashion seperti Egg, C awaii!!, Seventeen, dan $\mathrm{H}$ anachuu memuat foto serta mengupas gaya berpakaian mereka. D ari situlah gal kemudian terbagi menjadi beberapa jenis berdasarkan gaya masing-masing. M enurut Kazafustan dan Pattaya (2016), di antaranya adalah sebagai berikut:

1. Kogal: yaitu gal yang terdiri dari siswi-siswi SM U. Kata "ko" di sini diambil dari "kookoo" yang berarti SM U. Ciri khas dari K ogal ini adalah meskipun memakai seragam sekolah tetapi mereka tetap tampil fashionabledengan cara men gecat rambut dan memodifikasi seragam mereka sedemikian rupa. M isal nya, membuat ukuran rok jadi lebih pendek, kemudian memakai loose socks sebagai pengganti kaos kaki seragam.

2. M agogal: serupa dengan $\mathrm{K}$ ogal, hanya saja $\mathrm{M}$ agogal adalah para siswi sekolah menengah pertama. Itulah mengapa disebut "mago" (cucu) karena usia mereka yang terbilang paling muda diantara jen is gal lainnya.

3. G anguro: berarti 'muka hitam'. Disebut demikian karena gal jenis ini memakai krim tanning atau krim penggelap kulit untuk membuat wajah mereka terlihat kecokelatan. Gaya ini terinspirasi dari gadis-gadis pantai $C$ alifornia yang berkulit cokelat. $\mathrm{G}$ anguro populer pada era 90 -an hingga akhir tahun 2000, namun tidak bertahan lama karena kemudian gaya ini 
berkembang menjadi tren-tren baru.

4. Yamanba (M anba): merupakan gaya turunan dari Ganguro. Kulit mereka dibuat sangat cokelat, bisa dibilang tingkat kegelapan kulitnya paling tinggi diantara jen is gal berkulit cokelat lainnya. M ereka suka men gaplikasikan warn a-warna neon yang terang pada gaya berpakaian. M isalnya, pada rambut, eye shadow, cat kuku, dan Iain-lain. Yamanba sen diri berasal dari kata "yama uba" yang berarti penyihir gunung.

5. Banba: merupakan versi yang lebih mencolok dari Yamanba dari segi berpakaian, namun memakai make up yang lebih tipis. M asih menggunakan warna neon, namun gayanya lebih terkesan girly dan lebih terang dari Yamanba. Sering menambahkan ornamen glitter serta sentuhan berkilau pada bagian rambut.

6. Bibinba/ B -gal: adalah sebutan untuk gal yang men gusung style Hip-H op dan RnB. Tampilannnya terlihat lebih sporty serta identik dengan pernak pernik berwarna emas.

7. O negal: sebutan untuk gal yang telah lulus SM A hingga menginjak usia 20 tahunan. Biasanya adalah mahasiswi. D aripada fashion dengan tabrak warna, gaya gal yang satu ini lebih mengutamakan penampilan dengan mengenakan merekmerek ternama seperti Louis Vuitton, C hanel, C hristian Dior, Gucci, dan lain-tain.

8. K igurumin: $G$ al yang mengenakan piyama terusan yang disebut kigurumi. Bentuk piyama ini biasanya mengadaptasi bentuk binatang-binatang lucu seperti panda, atau tokoh kartun ternama yang berbentuk binatang seperti W innie the Pooh, Pokemon, dan lain sebagainya.

9. H imegal: adalah $\mathrm{G}$ al yang berdandan layaknya putri-putri Eropa abad ke-17. G aya yang diusung biasanya adalah gaya V ictoria atau Lolita yang identik dengan renda-renda dan rok yang mengembang serta rambut berwarna pirang. Mereka biasa memakai busana yang sangat mahal dari produk Liz Lisa dan Jesus Diamante.

10.G al K ei: bisa dikatakan ini adalah gaya gal yang paling mod- 
ern. Tampilannya lebih simpel dibanding gaya gal yang lain, namun tetap mencolok. Kuncinya adalah dengan memadukan beberapa unsur dari berbagai macam gaya seperti A mekaji (A merican Style), M ilitary style, Psyche, Bohemian, Punk Rock, dan lain sebagainya.

11. Gal-0 h: adalah gal versi pria. Gal-0 h di sini tidak bisa disamaartikan dengan lelaki transgender yan g cara berpakaian maupun perilakunya menyerupai wanita. Sejatinya mereka adalah lelaki yang gemar menabrak pakem fashion.

12.Kyoba-boy: merupakan versi lelaki dari Yamanba. A ksesoris yang digunakan terlihat berlebihan terutama pada tas.

M enurut Kudoka (2009), meskipun jika dilihat dari segi gaya berpakaian, komunitas gal terbagi ke dalam beberapa jenis, mereka memiliki kesamaan yang sudah menjadi identitas atau hal yang erat kaitannya dengan keberadaan gal.

Pertama, adalah pusat perbelanjaan Shibuya 109 (ichi maru kyuu). Terletak di pusat distrik Shibuya dan disebut 109 karena buka pada pukul 10:00 AM dan tutup pada pukul 09:00 PM. Para gal biasa menyingkatnya menjadi $M$ aru Kyuu saja. Tempat ini merupakan pusat fashion yang san gat terkenal di mana setiap minggunya selalu ada update dari barang-barang terkini. Tidak heran daerah tersebut menjadi spot berkumpulnya para gal yang notabene adalah pecinta fashion.

Kedua, adalah para-para dance (tarian para-para), yaitu sebuah tarian yang mengutamakan sinkronisasi gerakan terutama di bagian tangan. Disebut para para karena, gerakan tangan tersebut tampak terlihat seperti berjatuhan namun teratur. Tarian ini kerap dilakukan oleh para gal dengan tujuan mulai dari hanya untuk mengisi waktu luang hingga dibawa ke taraf profesional. Dari para-para dance ini kemudian muncul istilah yang disebut $\mathrm{G}$ al Circle (gyaru saakuru). M engapa disebut circle, karena saat menarikan para-para, pemimpin biasanya berdiri di tengah dengan posisi lebih tinggi dan bertugas sebagai instruktur. Kemudian, sang pemimpin dikelilingi oleh penari inti dalam sebuah lingkaran kecil, dan an ggota yang lain akan membentuk lingkaran 
baru mengelilingi para penari inti, dan seterusnya hingga terbentuk sebuah lingkaran besar berlapis-lapis. C ircle ini bisa disamakan dengan klan atau geng. Jadi semakin besar circle, maka semakin kuat pula eksistensi geng tersebut di dalam komunitas gal. Ketiga, tentu saja tidak lain dan tidak bukan adalah $\mathrm{G}$ al moji, yaitu huruf yang digunakan oleh para gal dalam berinteraksi antarsesama melalui surat elektronik dengan media telepon seluler. M en genai gal moji lebih dalam akan dijelaskan pada bagian selanjutnya.

\subsection{GAL MOJI}

Para gal tidak pernah lepas dari telepon seluler. Benda tersebut sangat penting bagi mereka karena merupakan sarana untuk saling berinteraksi dan menjalin komunikasi baik antarsesama gal maupun dengan individu lain di luar komunitas tersebut. Jika mengawinkan kata "gal" dengan kata "telepon seluler" maka yang akan muncul adalah "gal moji", yaitu huruf yang digunakan oleh para gal untuk menulis surat elektronik atau pesan singkat pada telepon seluler. A pakah yang membedakan gal moji den gan huruf Jepang (moji) pada umumnya? Untuk lebih memberi gambaran mengenai bentuk gal moji, mari lihat tulisan berikut ini:

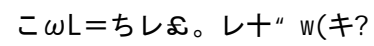

(Sifow, 2005)

Sepintas tulisan di atasterlihat seperti deretan input galat yang tidak memiliki arti. N amun, jika ditulis den gan moji biasa, maka sejatinya akan terbaca seperti berikut:

こんにちは。げんき?

(Sifow, 2005)

Pada awalnya memang tampak sulit dibayangkan, namun inilah gal moji.

A pakah sesungguhnya gal moji? G al moji atau yang biasa disebut juga dengan $\mathrm{H}$ eta moji (heta: unskillful) adalah huruf-huruf yang dibentuk ulang atau dimodifikasi sedemikian rupa sehingga bentuknya menjadi lebih menarik yang tetap didasari oleh bentuk 
atau bunyi asli huruf yang bersangkutan. Bentuk gal moji merupakan kombinasi dari huruf hiragana, katakana, kanji, simbol matematika, huruf latin, huruf Yunani, huruf Rusia, nomornomor, termasuk angka Romawi, dan berbagai macam variasi karakter lainnya yang dapat digeneralisasikan dengan tulisan Jepang kemudian diproses dengan software pada komputer ataupun telepon seluler.

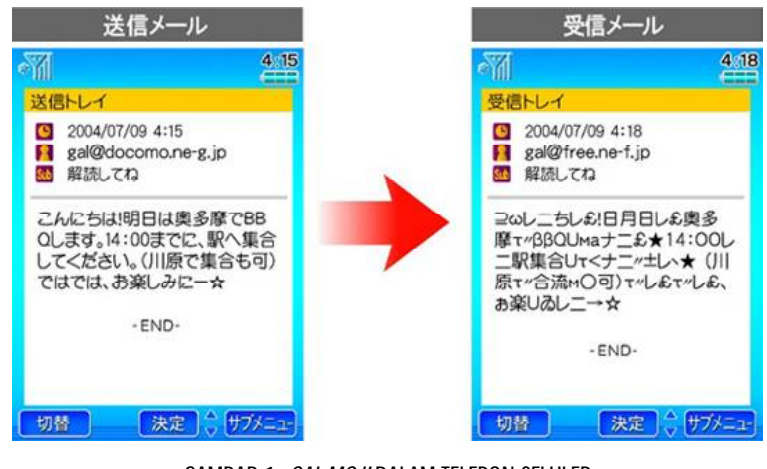

GAMBARI: GALMgI DALAMTEPONSHUR

G al moji banyak digunakan untuk mengirim surat elektronik atau pesan singkat via telepon seluler, dan biasanya dalam konteks non-formal. Dibandingkan dengan huruf Jepang biasa, mengetik teks pesan den gan menggunakan gal moji sebenarnya memerlukan teknik, juga membutuhkan lebih banyak usaha dan waktu, mengingat banyaknya jumlah karakter huruf yang harus digunakan. Tulisan yang dihasilkan pun akan sulit dilihat dan dimengerti pada awalnya, namun akhirnya akan menimbulkan ketertarikan tersendiri dikarenakan bentuknya yang lucu dan aneh.

Dalam "G yaru M oji H eta M oji Kooshiki Book" (2004) yang disusun sendiri oleh komunitas gal Shibuya, ada beberapa ketentuan atau aturan tidak baku mengenai cara membuat atau membentuk gal moji, di antaranya:

1. Melepaskan masing-masing bagian atau membuat huruf menjadi berantakan.

Misalnya, huruf hiraganarw」 memiliki dua buah garis pembentuk. Selanjutnya adalah mencari garis yang bentuknya

mirip seperti itu. G aris sebelah kiri bentuknya mirip dengan huruf 
hiragana $\ulcorner し\lrcorner$, sedangkan garis yang sebelah kanan, bentuknya cocok dengan tanda pengulangan $\Gamma>$. Berikutnya, menggabungkan kedua karakter tersebut, 「し」+「〉」=「し〉」. Selain menggunakan「८」 dapat juga digunakan huruf katakanarレ」 sebagai alternatif, sehingga bentuk yang diperoleh menjadi 「レ>」.

Contoh lainnya, huruf hiragana 「ほ」bisa ditulis dengan 「 (ま 」 (tanda kurung buka dan 「ま」.

2. Memisahkan bagian "hen" dan "tsukuri" (berlaku untuk huruf kanji).

C ara kerjanya serupa dengan poin pertama, yaitu melepaskan bagian sebelah kiri (hen) dan bagian sebelah kanan (tsukuri), kemudian digabungkan kembali. M isalnya, kanji 「私」terdiri dari dua buah bagian kanji, yaitu 「禾」. Setelah dipisahkan, kemudian kedua kanji tersebut digabungkan kembali sehingga menjadi 「禾么!.

C ontoh lainnya, kanji「校」 ditulis menjadi 「木交」.

3. Mencari simbol atau huruf yang bentuknya mirip sebagai pengganti.

Poin ketiga ini berlaku untuk huruf yang hanya terdiri dari satu bagian saja sehingga tidak bisa dipisah-pisah. M isalnya, huruf

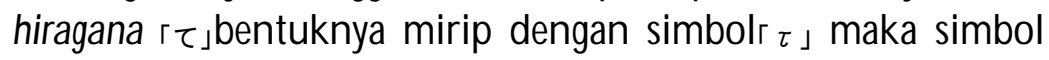
tersebut bisa digunakan sebagai pengganti huruf $[\tau$ ]

Contoh lainnya adalah huruf hiragana $\Gamma_{\text {世 }}$ disubstitusi dengan huruf $[$ 世」 yang diadopsi berdasarkan kemiripan bentuk.0

4. Mencari dan memakai huruf luar (Romaji, Rusia, dan Iainlain).

Jika tidak menemukan simbol maupun huruf yang bentuknya mirip, maka cara yan g terakhir ini bisa digunakan, yaitu memakai Romaji, huruf Rusia, atau huruf luar lainnya yang cara baca atau bunyinya sesuai dengan huruf yang akan disubstitusi. M isalnya, huruf hiragana「ね」 diganti dengan гй ё」 yang meskipun bentuknya tidak ada kemiripan sama sekali, namun memiliki cara baca atau bunyi yang sama. 
Contoh lainnya adalah huruf hiragana「れ」 ditulis dengan Гя ё 」.

Seperti yang telah disebutkan sebelumnya, dalam pembentukan huruf ini sebenarnya tidak ada ketentuan baku. Terdapat begitu banyak huruf serta simbol yang dapat digunakan dengan bebas sesuka hati sehingga masih ada banyak kemungkinan terbentuknya huruf-huruf baru. D alam pengaplikasiannya pun, gal moji biasa dikombinasikan dengan emoji dan kao moji, seperti dalam contoh berikut ini:

-ラ丁 ᄀ"の千ヶ“ノト、な

へ) テテこうЙё\&

・ライブのチケット、なんとか取れたヨ(^จ^) 行こうね

\&

(Kojiro, 2006)

Ket:

$\left({ }^{\wedge} \nabla^{\wedge}\right) \rightarrow$ Kao moji

$B \rightarrow E m o j i$

Selanjutnya akan diperlihatkan beberapa contoh isi pesan singkat yang ditulis den gan gal moji berdasarkan tema yang dekat dengan kehidupan gal sehari-hari.

A sobi hen (bersantai)

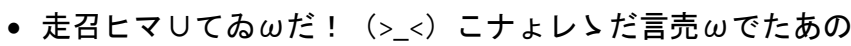
マンカ"、イ昔り（こレ〉ってレ〉レ〉?

・超ヒマしてるんだ！（>ðここないだ読んでたあのマンガ、 借りにいっていい?

(Shibuya H eta M oji Fukyuuinkai, 2004: 8-9)

Love hen (percintaan)

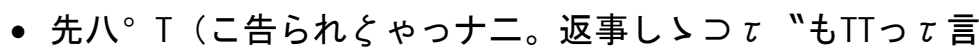

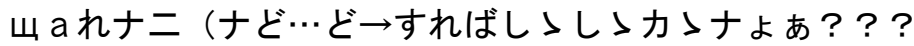

・先パイに告られちゃった。返事いつでもイイって言われた

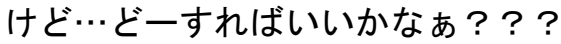


(Shibuya H eta M oji Fukyuuinkai, 2004: 20-21)

$G$ akkou hen (sekolah)

- 日乍日の数学の宿是頁やっナニ?干ョー難 $U<\tau$ 、全然 $\tau "$ き $\mathrm{f}$ よカっナニヨ。あ $ட \subset \tau$ ”解き方孝文え $\tau$ 。

- 昨日の数学の宿題やった?チョー難しくて、全然できなか ったヨ。あよで解き方教えて。

(Shibuya H eta M oji Fukyuuinkai, 2004: 28-29)

Baito hen (kerja sambilan)

・ 旧寺給カ、“高く $\tau$ 走召ラクナょ才ススメ八"Tトあ あ? $\tau$ も、ヤ八"十

・ 時給が高くて超ラクなオススメバイトある?でも、ヤバイ のはやだよ之

(Shibuya H eta M oji Fukyuuinkai, 2004: 40-41)

D eeto hen (kencan)

- 日乍日三フ"ヤで $\neq \vee$ Tメナょ] LC言舌Uてナニけட C"、言隹ナニ" っナニの?気にナょって、夜目民れナょ カノっナニョ。元カノ?

・昨日シブヤでキレイメなコと話してたけど、誰だったの? 気になって、夜眠れなかったヨ。元カノ?

(Shibuya H eta M oji Fukyuuinkai, 2004: 50-51)

$N$ aisho hen (rahasia)

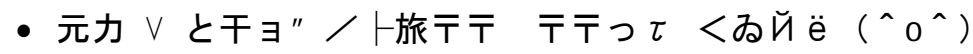
为力 $\vee \equiv \mid$ 二は内糸者ナニ" $\ni \omega \bullet$

- 元カレとチョット旅行・行ってくるね(^゚^) 妟カレシに は内緒だよんり

(Shibuya H eta M oji Fukyuuinkai, 2004: 58-59)

Salah satu keunikan lain dari penggunaan gal moji ini adalah huruf yang digunakan berubah-ubah sesuai dengan tingkatan perasaan pengirim. Mari lihat beberapa contoh berikut. Tingkatan perasaan pengirim pesan ditandai dengan banyak 
sedikitnya jumlah tanda untuk perasaan positif, dan tanda untuk perasaan negatif.

・「だい〜すき」

ナご〜いミき

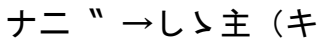

ナニ゙ $\Rightarrow$ 丁女子（キ

-「きらい」

(キらい

(キЯ aし〉

$\neq$ Я а $\mathrm{T}$

・「がんばれ」

カジ $\omega$ ば れ

カぶん(よ゙れ

カ\” WL" Я ё

-「ごめんね」

] : メンネ

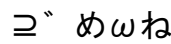

$=$ " $\mathrm{M} \ddot{\mathrm{e}} \omega \breve{\mathrm{U}} \ddot{\mathrm{e}}$

Dari beberapa contoh di atas dapat dilihat bahwa semakin kuat perasaan pen girim pesan, maka semakin aneh pilihan huruf yang digunakan untuk menulis teks pesan.

Mengapa para gal senantiasa menggunakan huruf yang notabene sulit dibaca serta membutuhkan banyak waktu dalam penulisannya?Tanabe (2007) menyebutkan, pen ggunaan gal moji dipicu oleh beberapa alasan, salah satunya adalah menyangkut kerahasiaan. Huruf-hurufnya yang sulit dibaca membuat kerahasiaan isi pesan di dalam telepon seluler mereka terjaga dari orang tua, guru, bahkan dari penumpang lain saat tengah berada di kereta yang penuh dan sesak. Selain itu, mengirim pesan dengan menggunakan gal moji dianggap sebagai tandakasih sayang kepada orang yan g dikirimi pesan, sekaligus mencerminkan keakraban atau persahabatan. Ada anggapan pula bahwa perasaan yang jujur akan lebih mudah tersampaikan jika menggunakan gal moji.

Pada awalnya gal moji lebih banyak digunakan atau oleh gal berusia belasan tahun yang masih duduk di bangku SM P dan 
SMU, namun saking populernya huruf tersebut, akhirnya pemakaian meluas hingga ke remaja yang berusia antara 20 tahun sampai menjelang 30 tahun, bahkan laki-laki pun menggunakannya walaupun memang terbatas hanya di kalangan tertentu saja. M asa atau zaman pembentukan gal moji sendiri tidak diketahui secara persis, namun fenomena yang menyita perhatian publik ini pertama kali diangkat oleh media massa pada tahun 2002.

Seiring dengan meluasnya penggunaan huruf tersebut, maka semakin kencang pula kritik yang muncul dari masyarakat yang tidak setuju dengan penggunaan gal moji. $\mathrm{H}$ al ini disebabkan oleh kesulitan orang-orang yang tidak mengerti gal moji ketika harus membaca isi pesan yang mereka terima yang kebetulan menggunakan huruf tersebut. Masalah ini tak jarang menimbulkan konflik sehingga di masyarakat umum muncul rasa antipati terhadap gal yang menggunakan gal moji. Ditambah lagi dengan adanya beberapa kasus seperti, gal moji dipakai untuk mengerjakan pekerjaan rumah, karyawati menggunakannya saat di tempat kerja, atau gal moji digunakan untuk menulis data riwayat hidup ketika melamar pekerjaan.

Kasus pengucilan terhadap mereka yang men ggunakan gal moji pun tak jarang terjadi. Sejak awal booming-nya huruf ini, yaitu pada tahun 2002 hingga tahun 2006, di sebuah lingkungan SM P terdapat grup siswi yang menggunakan dan tidak menggunakan gal moji. Para siswi yang menggunakan gal moji, terpisah dari komunitas dan disebut "bagal" ("ba" berasal dari kanji >m yang berarti kubu atau aliran). Komunitas bagal ini men dapat banyak kecaman dari mereka yang tidak menggunakan gal moji.

A kan tetapi, di antara banyaknya kecaman serta kritik, gal moji pun masih memberikan keuntungan tersen diri bagi pihakpihak tertentu, salah satunya datang dari bisnis hiburan. Kepopuleran huruf ini menarik perhatian para penggiat industri hiburan khususnya di bidang musik untuk membuat lirik lagu dengan gal moji, dan hal tersebut direalisasikan melalui tempattempat karaoke. Maka tidaklah aneh jika ditemukan lagu-lagu 
di tempat karaoke yang teks liriknya ditulis dengan gal moji.

Fenomena gal moji ini memang sarat dengan pro dan kontra. Namun, hal yang terjadi di kalangan anak muda seperti ini memang tidak bisa dihindari. Fenomena mirip dengan pola serupa pun pernah merambah di kalangan anak muda Indonesia sekitar satu dekade ke belakang. Kita mengenalnya dengan sebutan "Bahasa Alay" yang mana penulisan huruf alfabet dimodifikasi dengan mencampurkan bilangan numerik, simbol, serta tanda baca. Fenomena tersebut dirasa wajar terjadi di kalangan mereka, mengingat sisi psikologis pelaku serta penggunanya masih belum stabil dan cenderung memiliki keinginan untuk membentuk dunia sendiri. D unia yang hanya dihuni oleh teman-teman dekat atau komunitas mereka saja yang tentunya tidak akan dimengerti oleh orang dewasa.

\section{SIMPULAN}

Dari penjelasan pada bab sebelumnya, maka dapat diambil beberapa simpulan menyan gkut gal moji sebagai fen omena dalam bahasa Jepang ragam surat elektronik pada komunitas gal, di antaranya adalah sebagai berikut.

1) Latar belakang penggunaan gal moji adalah untuk menjaga kerahasiaan isi pesan dari orang tua, guru, serta penumpang di kereta.

2) Sifat pembentukan gal moji adalah manasuka, berdasarkan kemiripan bentuk dan kesamaan bunyi.

3) Mengirim pesan dengan menggunakan gal moji dianggap sebagai tanda sayang serta diartikan sebagai keakraban dan persahabatan. Pemilihan huruf pun erat kaitannya dengan tingkatan perasaan pengirim pesan.

4) Penggunaan gal moji yang tidak pada tempatnya, tidak menyesuaikan dengan situasi serta kondisi, menuai kontra di kalangan masyarakat luas. $\mathrm{N}$ amun, tidak bagi pebisnis yang menjadikan para gal sebagai sasaran pasar mereka. 


\section{SUM BER REFERENSI}

Kazafustan. Gyaru Bunka. Kyooyoo Gakubu. http://www.qmss.jp/i-student/i-student/utokyo/work3/3-10.pdf

Kudoka, Yoko. (2009). Gyaru Bunka ni Miru Atarashii Tokusei. S\&E Soogoo Kenkyuusho. http://www.mitsuifudosan.co.jp/s-e/infomation/pdf/report_091221.pdf

Kojiro. (2006). http://blog.livedoor.jp/kojiro_turbo/archives/50393155.html

Pattayaa, Kospan. (2016). Nihon no Street Fashion no Gyaru Bunka. Nihongo Nipponbunka Kenshuu Puroguramu Kenshuu Repooto-shuu. Volume 31. http://ir.lib.hiroshimau.ac.jp/files/public/4/42505/20170216140947371023/ReportJTP_31_28.pdf

Shibuya Heta Moji Fukyuuinkai. (2004). Gyaru Moji Heta Moji Kōoshiki Book. Kabushikigaisha Jitsugyononi Honsha.

Sifow. (2005). http://blog.livedoor.jp/sifow/archives/2005-05.html

Tanabe, Kazuko. (2005). Speech Patterns of Japanese Girls or Gals: Symbol of Identity \& Opposition to Power. Queen Mary's OPAL \#3 Occasional Papers Advancing Linguistics.

(2007). The Mechanism of Forming Cyber-Dialect in terms of Communities of Practice -The Case of Japanese gal's computer mediated communication-. Japan Women's University.

http://plaza.rakuten.co.jp/love2kaomoji/5007

http://www.gal-moji.com/moji/gyaru_moji.asp

http://www.kanjiclinic.com/kc69final.htm 